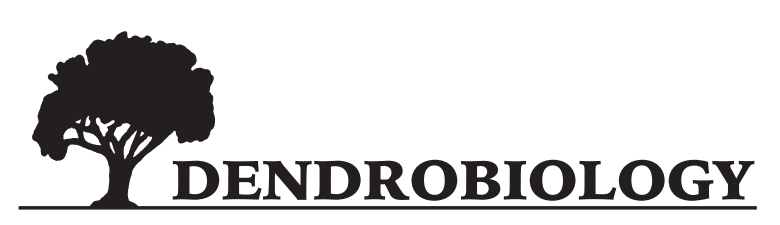

2020, vol. 84, 1-11

https://doi.org/10.12657/denbio.084.001

\author{
Ertugrul Bilgili, Kadir Alperen Coskuner*, Murat Ozturk
}

\title{
Leaf area - sapwood area relationship in Scots pine (Pinus sylvestris L.) under mistletoe (Viscum album ssp. austriacum) infection
}

Received: 14 June 2020; Accepted: 18 September 2020

\begin{abstract}
Leaf area is linearly correlated with sapwood area in trees. The linearity of this relationship can be affected by some biotic and abiotic factors. Mistletoes are hemi parasitic plants that take up water and mineral nutrients from their hosts and affect host physiological responses. There is no conclusive evidence to show the effect of pine mistletoe (Viscum album ssp. austriacum) on leaf area and sapwood area relationship in Scots pine trees (Pinus sylvestris L.) at tree level. The aim of this study is to determine and quantify the effect of pine mistletoe on the structural variation of leaf area and sapwood area relationship at tree level in Scots pine. A total of 18 mistletoe infected and 12 uninfected Scots pine trees were destructively sampled. All needles and mistletoes were completely removed from sampled trees to determine needle and mistletoe characteristics, biomass and leaf area. Sapwood areas at breast height $(\mathrm{BH})$ and at crown base height $(\mathrm{CBH})$ were determined from wood discs taken from $\mathrm{BH}(1.3 \mathrm{~m})$ and $\mathrm{CBH}$. Sapwood area was delineated by benzidine staining method. Pearson correlation, t-test and regression analyses were conducted to determine the relationship between sapwood area and needle-mistletoe leaf area relationships. The results indicated that both the relationships between sapwood area and leaf area in uninfected, and sapwood area and total leaf area (needle plus mistletoe leaf only) in infected trees were linear. However, the slope of regression equation for mistletoe infected trees was considerably lower when compared to the uninfected trees. As for the variation of the sapwood area along the stem below live crown, there was a slight difference between sapwood area at $\mathrm{BH}$ and $\mathrm{CBH}$. The study showed also that mistletoe infection led to a significant reduction in needle size (length, width, area and weight) in Scots pine trees. Significant relationships were found between the sapwood area and leaf area in this study. The results of this study may help fill the gap in the knowledge concerning the impacts of pine mistletoe on the dynamics of Scots pine trees.
\end{abstract}

Keywords: Leaf area, sapwood area, Scots pine, pine mistletoe

Address: E. Bilgili, K. Alperen Coskuner, M. Ozturk, Karadeniz Technical University, Faculty of Forestry, 61080, Trabzon, Turkey, e-mail: kacoskuner@ktu.edu.tr

${ }^{*}$ Corresponding author

\section{Introduction}

Leaf area or leaf biomass is linearly correlated with sapwood area in trees (Albrektson, 1984; Mäkelä et al., 1995; Whitehead, 1978). This is based on the pipe model theory (Shinozaki et al., 1964), which states that a given unit of foliage requires a given unit of sapwood area to supply water (Kendall \& Brown, 1978; Waring et al., 1982; Whitehead, 1978). Linear relationship between sapwood cross sectional area and leaf area/biomass has been used to estimate leaf area for a number of conifer and hardwood tree species 
(Bartelink, 1997; Grier \& Waring, 1974; Meadows \& Hodges, 2002; Whitehead, 1978). However, a correction is required for the change in sapwood area at different levels from the base of the crown down to ground, as the amount of conducting area at the base of the crown and at different heights below crown base can differ greatly (Morikawa, 1974; Waring et al., 1982). Moreover, the linearity of this relationship can be affected by some biotic and abiotic factors and this effect particularly appears in the slope of regression lines (Lambers et al., 1998). The slope of this relationships is known to vary with species (Kaufmann \& Troendle, 1981; Waring et al., 1982) and such abiotic factors as site quality (Whitehead, 1978) and growing condition (Brix \& Mitchell, 1983). Brix and Mitchell (1983) found that thinning and fertilizer treatments significantly increased the slope of the regression of leaf area and sapwood area. It is also affected by stand density, age and site quality (Pearson et al., 1984). Pearson et. al., (1984) found that the leaf area per unit sapwood area ranged from 0.20 to $0.57 \mathrm{~m}^{2}$ in lodgepole pine stands. Whitehead (1978) reported that the relationship between leaf area and sapwood area was independent of tree spacing in Scots pine stands. Dean and Long (1986) analyzed the variation of the sapwood-leaf area ratio for mature stand and saplings, and found the slope of the regression for saplings $\% 40$ greater than that of mature trees. Results from other researchers suggest that the leaf area to sapwood area ratio vary with water availability and average vapor pressure deficit (Mencuccini \& Grace, 1995). However, less attention has been given to the investigation of biotic factors such as mistletoe, which might influence leaf area and sapwood area relationship of mistletoe-infected trees.

Mistletoes are a group of obligate vascular hemi parasites that reduce the growth and productivity of their hosts (Mathiasen et al., 2008). These parasitic plants directly take up water and mineral nutrients from their hosts and affect host physiological responses such as photosynthesis and transpiration. The transpiration rate and stomatal conductance of mistletoes are higher than those of hosts (Mathiasen et al., 2008; Ullmann et al., 1985). Drought stress exacerbated by mistletoes (Glatzel \& Geils, 2009) and coupled by higher transpiration rate developing with decreasing xylem water potential in host branches lead to reduced photosynthetic rate of host (Mathiasen et al., 2008). Therefore, increased growth loss (Barbu, 2012; Bilgili et al., 2020; Bilgili et al., 2018; Ozturk et al., 2019), altered resource allocation (Tinnin \& Knutson, 1980) and mortality (Rigling et al., 2010) are the typical results of mistletoe infection. In addition, mistletoe infection causes crown degradation by reducing the number of needles, needle length and width and the longevity of needles on the infected branches (Barbu, 2012; Rigling et al., 2010).
Previous studies have clearly shown the effects of mistletoe on tree growth (Bilgili et al., 2020; Bilgili et al., 2018; Kanat et al., 2010), wood anatomy (Gol et al., 2018; Ozturk et al., 2019), biology (Mutlu et al., 2016b; Persoh et al., 2010), physiology (Ehleringer et al., 1986; Glatzel \& Geils, 2009; Mutlu et al., 2016a) and morphology (Rigling et al., 2010) of host plants. In addition, the relationship between leaf area and sapwood area have been examined and documented in many broadleaved (Meadows \& Hodges, 2002) and conifer species (Bancalari et al., 1987; Waring et al., 1982) including Scots pine (Albrektson, 1984; Berninger \& Nikinmaa, 1994; Whitehead, 1978). To our knowledge, there are few studies available (e.g., (Rigling et al., 2010; Tennakoon \& Pate, 1996) on the effect of mistletoe on structural balance of host trees. However, these studies have branch level experiments and, thus, may underestimate the effect of mistletoe on structural variation of leaf area or biomass and sapwood area relationship at the whole tree level. Moreover, there is no conclusive evidence to show the effect of pine mistletoe on leaf area and sapwood area relationship in Scots pine trees at tree level.

The main objective of this study was, therefore, to determine and quantify the effect of pine mistletoe (Viscum album ssp. austriacum) on the structural variation of leaf area and sapwood area relationship at tree level in Scots pine (Pinus sylvestris L.). We hypothesized $i$ ) that pine mistletoe infection has an effect on the structural variation of leaf area and sapwood area relationship in Scots pine, and ii) that sapwood areas differ along the stem below crown base in mistletoe infected Scots pine. In addition, we analyzed the effect of pine mistletoe on leaf characteristics of Scots pine.

\section{Materials and Methods}

\section{Study Area}

The study was conducted in Torul State Forest Enterprise, Gumushane, Turkey located at $40^{\circ} 37^{\prime} 20^{\prime \prime} \mathrm{N}$ and $39^{\circ} 14^{\prime} 49^{\prime \prime E}$ (Fig. 1a). The altitude of ten sampling plots varies between 990 and $1780 \mathrm{~m}$ and the mean altitude was about $1470 \mathrm{~m}$ with an average slope of about 67 percent (Table 1). Soils in the area are shallow, and loam and sandy loam. The study area has a humid continental climate with cold and snowy winters and warm summers. Average annual air temperature varies from 4.3 to $16.4{ }^{\circ} \mathrm{C}$ and, the average annual precipitation is $463.7 \mathrm{~mm}$ (TSMS, 2020). The study site was composed of natural, pure stands of Scots pine (Pinus sylvestris L.) (Fig. 1b) with few Oak (Quercus ssp.) and Juniper (Juniperus ssp.) individuals in the understory. The mean stand basal 
Table 1. Summary statistics (maximum, minimum, mean and standard error of means (between brackets)) of ten sampled site, stand and mistletoe uninfected-infected tree characteristics

\begin{tabular}{|c|c|c|c|c|c|c|c|c|}
\hline \multicolumn{3}{|c|}{ Stand characteristics } & & & Unit & Max & Min & Mean $( \pm$ SE $)$ \\
\hline \multicolumn{3}{|c|}{ Crown closure } & & & $\%$ & 90 & 15 & $50.3(3.1)$ \\
\hline \multicolumn{3}{|c|}{ Altitude } & & & $\mathrm{m}$ & 1780 & 990 & $1468.8(41.2)$ \\
\hline \multicolumn{3}{|c|}{ Slope } & & & $\%$ & 100 & 25 & $67.7(4.0)$ \\
\hline \multirow{2}{*}{\multicolumn{2}{|c|}{ Tree characteristics }} & & \multicolumn{4}{|c|}{ Uninfected $(\mathrm{n}=12)$} & \multicolumn{2}{|c|}{ Infected $(n=18)$} \\
\hline & & Unit & Max & Min & Mean $( \pm$ SE $)$ & Max & Min & Mean $( \pm$ SE $)$ \\
\hline \multicolumn{2}{|c|}{ Diameter at breast height } & $\mathrm{cm}$ & 31.0 & 13.0 & $21.2(1.6)$ & 36.0 & 12.0 & $21.0(1.1)$ \\
\hline \multicolumn{2}{|c|}{ Tree height } & $\mathrm{m}$ & 19.0 & 6.3 & $12.7(1.1)$ & 13.1 & 6.1 & $8.9(0.4)$ \\
\hline \multicolumn{2}{|c|}{ Crown base height } & $\mathrm{m}$ & 12.8 & 0.1 & $5.5(1.4)$ & 4.4 & 0.3 & $1.8(0.2)$ \\
\hline \multicolumn{2}{|c|}{ Crown length } & $\mathrm{m}$ & 8.7 & 4.6 & $7.2(0.3)$ & 10.2 & 4.8 & $7.1(0.2)$ \\
\hline \multicolumn{2}{|c|}{ Crown width } & $\mathrm{m}$ & 6.3 & 2.5 & $4.4(0.3)$ & 12.8 & 2.8 & $5.3(0.4)$ \\
\hline \multicolumn{2}{|l|}{ Age } & Year & 91.0 & 42.0 & $42.0(4.8)$ & 84.0 & 28.0 & $55.9(3.0)$ \\
\hline \multirow[t]{4}{*}{ DMRS } & Upper part & & - & - & - & 2.0 & 0.7 & $1.6(0.1)$ \\
\hline & Middle part & & - & - & - & 1.7 & 0.5 & $1.2(0.1)$ \\
\hline & Lower part & & - & - & - & 1.3 & 0.3 & $0.8(0.1)$ \\
\hline & DMRS (6 Class) & & - & - & - & 4.5 & 0.9 & $2.9(0.2)$ \\
\hline
\end{tabular}

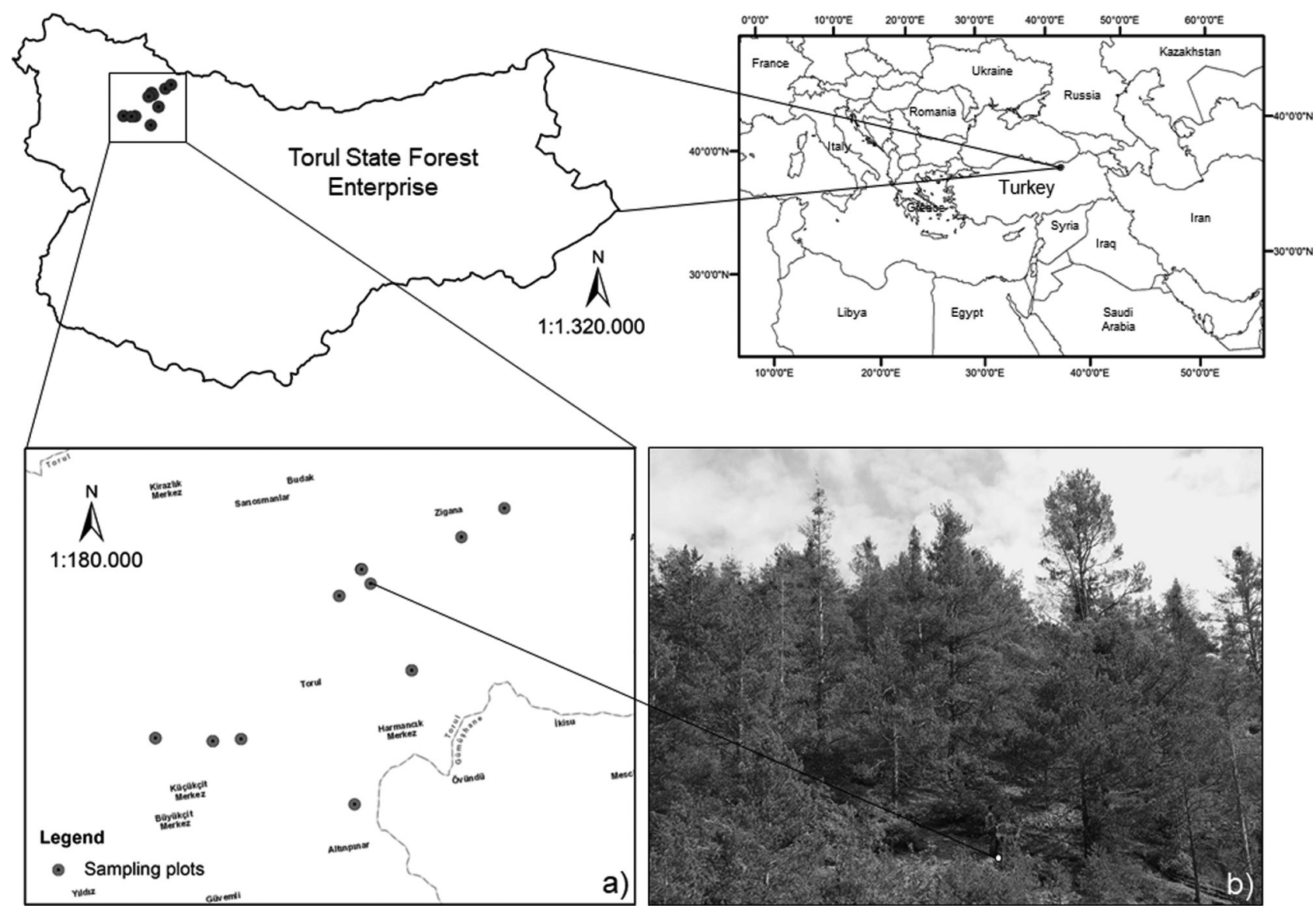

Fig. 1. Locations of ten sampling plots in in the Torul State Forest Enterprise (a) and one of the sampling plots (b)

area was $7.7 \mathrm{~m}^{2} \mathrm{ha}^{-1}$ and the mean stand volume was $47.7 \mathrm{~m}^{3} \mathrm{ha}^{-1}$.

Stands were even-aged, and the overall site quality of the study area was medium (Site index $=15-17$ $\mathrm{m})$. Site description and characteristics of sampled stands and trees are given in Table 1.

\section{Tree sampling and mistletoe infection level determination}

A total of 30 Scots pine trees were destructively sampled from ten plots representing different site conditions. Of the trees sampled, 12 were uninfected and 18 were infected with mistletoe. All the trees 
were either open grown or those participating in the upper storey with other trees (i.e., dominant trees according to Kraft System) (Kraft, 1884). This was to eliminate the effect of competition and of other environmental factors. The selection of trees was made such that sampled trees represented a range of diameter at breast height (DBH) and mistletoe infection level determined according to six-class dwarf mistletoe rating system (DMRS) (Hawksworth, 1977). In DMRS, the crown is visually divided into three equal parts. Each third is rated as 0 for no mistletoe infection, 1 for light mistletoe infection (less than 50 per cent of the branches infected) and 2 for heavy mistletoe infection (more than 50 per cent of the branches infected). Ratings for each third section are summed up to obtain a total value for the whole tree. All trees were felled in autumn at the end of the needle expansion period.

\section{Needle and mistletoe leaf area determination}

All needles and pine mistletoes (Viscum album ssp. austriacum) were completely removed from sampled trees and weighed. Subsamples of needles (up to $10 \%$ of total fresh biomass) and all mistletoes were placed in nylon bags and taken to the laboratory for leaf area and dry-weight determinations. The samples of one-year-old needles were also sampled and packed for specific leaf area measurements in the laboratory. Needle samples were equally taken from mistletoe infected and uninfected branches. Results were based on average values. A total of 2394 mistletoes were collected from 18 mistletoe infected trees. Of these, 90 mistletoes were sampled and separated into mistletoe branch and leaf to determine mistletoe leaf/branch biomass ratio. Mistletoes were also aged morphologically (Dawson et al., 1990). The needle samples and mistletoes were dried to a constant weight for 24 hours at $105^{\circ} \mathrm{C}$ and weighed to the nearest $0.01 \mathrm{~g}$ in the laboratory. Final needle and mistletoe biomass determinations were made on the basis of oven-dry measurements.

Needle characteristics (needle length, width and weight) were determined based on 30 randomly selected one-year old needles (Mencuccini \& Bonosi, 2001). Needle length, width and areas were determined from digital images. To do this, the selected one-year-old needles were placed in white papers with invisible adhesive tape. All papers were placed in an incubator and dried for 24 hour at $105^{\circ} \mathrm{C}$. The papers including needles were scanned using a scanner (Hewlett Packard Scanjet G2410) at 1200 dpi resolution. Then, these digital images were processed with the Bs200ProP image analysis software (BAB Imaging Systems Ltd, Ankara, Turkey) to determine needle length, width and area. Needle area of each tree was calculated from the one-sided needle area and dry needle weight (Long \& Smith, 1988).

Specific leaf area of mistletoe was determined based on 30 randomly selected mistletoes. The leaves and branches of selected mistletoes were separated and 30 randomly selected leaves were placed in white papers. Then, the same procedure employed for the needles was followed for the determination of specific mistletoe leaf area. Total needle and two-sided mistletoe leaf areas $\left(\mathrm{kg} \mathrm{m}^{-2}\right)$ were then calculated using oven dry weights of needle and mistletoe leaf samples.

\section{Sapwood area measurements}

Sapwood area of sampled trees was determined from 5 to $10 \mathrm{~cm}$ thick wood discs taken from breast height $(1.3 \mathrm{~m})(\mathrm{BH})$ and crown base height $(\mathrm{CBH})$. Sapwood and heartwood were differentiated by benzidine staining method (Holz, 1959). In this method, a reagent was prepared by mixing aqueous solutions of benzidine and sodium nitrite. Benzidine solution was prepared by dissolving $5 \mathrm{~g}$ benzidine in $25 \mathrm{~g}$ hydrochloric acid (25\%) and adding the solution to one liter of water. Sodium nitrite solution was prepared by dissolving $100 \mathrm{~g}$ sodium nitrite in one liter of water (Rust, 1999). Solutions were then mixed shortly before the application. The reagent was applied with spray atomizer with air compressor on cross sectional area of wood discs and dyed the heartwood dark red and the sapwood yellow.

The area of sapwood was then calculated on each disc for $\mathrm{BH}$ and $\mathrm{CBH}$. Basal area and sapwood thickness of each disc were recorded to the nearest 0.5 $\mathrm{mm}$ with the average of two to four measurements taken at right angles. Then, sapwood cross-sectional area was calculated by subtracting heartwood area from the total cross-sectional area for each disc (Bancalari et al., 1987).

\section{Data analysis}

Pearson correlation analysis was undertaken to investigate the relationships between sapwood area at crown base and breast height, needle and mistletoe biomass, projected leaf area for needles and mistletoes and distance between $\mathrm{BH}$ and $\mathrm{CBH}$ values for each mistletoe infected and uninfected sampled trees. Spearman correlation analysis was undertaken to investigate the relationships between needle characteristics and mistletoe infection level (DMR) as the DMR is ordinal in measurement. An independent samples t-test was used to determine whether there was a significant difference between the means of tree, needle and mistletoe characteristics of infected and uninfected Scots pine trees $(\mathrm{P}<0.05)$. Before the 
analyses, Kolmogorov-Smirnov normality test was conducted on all variables. Linear regression analysis was conducted, and equations were developed using sapwood area as independent variable to predict needle and mistletoe biomass and projected leaf areas. All statistical analyses were performed using the statistical software SPSS, Version 23.0 (SPSS, 2015).

\section{Results}

A total of 30 trees (18 mistletoe- infected and 12 uninfected) were sampled in 10 representative plots. The sampled stands were almost homogeneous with regard to provenance, site and growing conditions (Fig. 1, Table 1). In mistletoe infected trees, sapwood area at $\mathrm{CBH}$ ranged from 105.6 to $461.6 \mathrm{~cm}^{2}$, sapwood area at BH from 91.2 to $596.6 \mathrm{~cm}^{2}$, needle biomass from 1.2 to $13.3 \mathrm{~kg}$, specific leaf area (SLA) from 41.7 to $66.2 \mathrm{~cm}^{2} \mathrm{~g}^{-1}$, projected leaf area 7.7 to $63.5 \mathrm{~m}^{2}$, mistletoe biomass from 0.1 to $12.9 \mathrm{~kg}$, mistletoe leaf biomass from 0.1 to $4.8 \mathrm{~kg}$ and mistletoe leaf area (two-sided) from 0.1 to $16.1 \mathrm{~m}^{2}$.

In uninfected trees, sapwood area at $\mathrm{CBH}$ ranged from 80.1 to $282.9 \mathrm{~cm}^{2}$, sapwood area at $\mathrm{BH}$ from 70.1 to $371.0 \mathrm{~cm}^{2}$, needle biomass from 2.2 to 14.6 $\mathrm{kg}$, specific leaf area (SLA) from 38.6 to $56.5 \mathrm{~cm}^{2} \mathrm{~g}^{-1}$ and projected needle area from 12.2 to $76.3 \mathrm{~m}^{2}$. Mean values of sampled tree characteristics and t-test results were given in Table 2 .

\section{Sapwood area - leaf area relationship}

The Pearson correlation analysis indicated that significant relationships exist between sapwood area at crown base and leaf area in uninfected and infected trees. The sapwood area at CBH had a significant positive correlation with projected needle area $(\mathrm{r}=$ 0.950, $\mathrm{p}<0.01)$ in uninfected trees. The sapwood area at $\mathrm{CBH}$ had a significant positive correlation

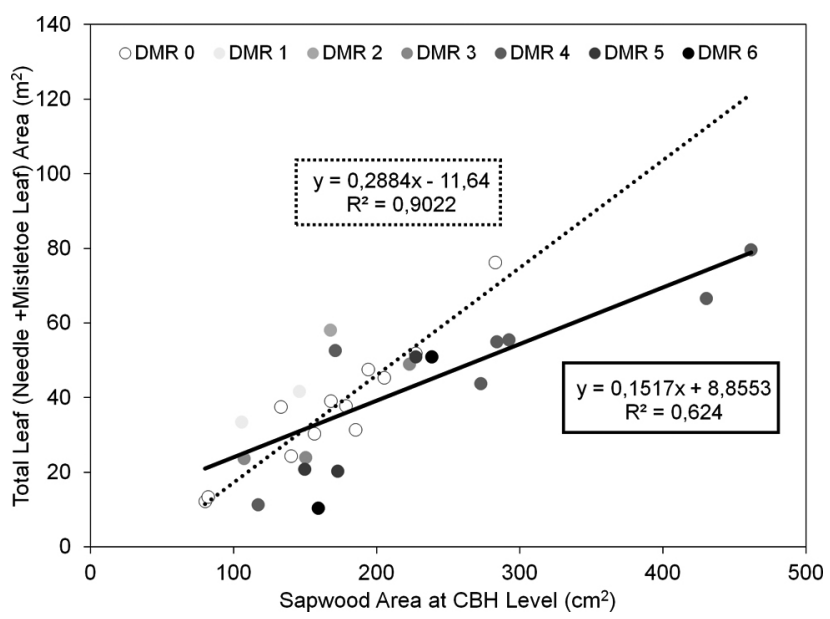

Fig. 2. The relationships between sapwood area at crown base height and total leaf (mistletoe leaf plus needle) area. Dashed line represent the relationships for uninfected trees. Solid line represent the relationships for pine mistletoe infected trees

Table 2. Summary statistics (means and standard error of means (between brackets)) and t-test results for uninfected and mistletoe infected trees. Significance values are indicated as: ${ }^{*} p<0.05$, and $n s=p \geq 0.05$. Percent change is calculated from the mean values of mistletoe uninfected and infected tree characteristics

\begin{tabular}{|c|c|c|c|c|c|}
\hline \multirow{2}{*}{ Sampled tree characteristics } & \multirow{2}{*}{ Unit } & Uninfected & Infected & \multirow{2}{*}{ Effect (p) } & \multirow{2}{*}{ Percent change from uninfected trees } \\
\hline & & Mean $( \pm S E)$ & Mean $( \pm$ SE) & & \\
\hline Diameter at breast height & $\mathrm{cm}$ & $21.2(1.8)$ & $21.0(1.5)$ & ns & -1.1 \\
\hline Tree height & $\mathrm{m}$ & $12.7(1.5)$ & $8.9(0.5)$ & * & -29.5 \\
\hline Crown base height & $\mathrm{m}$ & $5.5(1.5)$ & $1.8(0.3)$ & * & -66.2 \\
\hline Crown length & $\mathrm{m}$ & $7.2(0.4)$ & $7.1(0.3)$ & ns & -1.7 \\
\hline Crown width & $\mathrm{m}$ & $4.4(0.3)$ & $5.3(0.5)$ & ns & 21.9 \\
\hline Age & year & $65.3(5.4)$ & $55.9(4.0)$ & ns & -14.4 \\
\hline Sapwood area at $\mathrm{CBH}$ & $\mathrm{cm}^{2}$ & $169.5(16.6)$ & $215.4(24.1)$ & ns & 27.0 \\
\hline Sapwood area at $\mathrm{BH}$ & $\mathrm{cm}^{2}$ & $217.5(27.3)$ & $217.6(28.1)$ & ns & 0.1 \\
\hline Needle biomass ${ }^{1}$ & $\mathrm{~kg}$ & $8.0(1.1)$ & $6.9(0.8)$ & ns & -13.5 \\
\hline Projected needle area ${ }^{1}$ & $\mathrm{~m}^{2}$ & $37.2(5.0)$ & $36.7(4.1)$ & ns & -1.6 \\
\hline Total leaf biomass ${ }^{2}$ & $\mathrm{~kg}$ & $8.0(1.1)$ & $8.4(1.0)$ & ns & 4.7 \\
\hline Total leaf area ${ }^{2}$ & $\mathrm{~m}^{2}$ & $37.2(5.0)$ & $41.5(4.6)$ & ns & 11.5 \\
\hline Total green biomass ${ }^{3}$ & $\mathrm{~kg}$ & $8.0(1.1)$ & $10.8(1.5)$ & ns & 35.4 \\
\hline Needle characteristics & unit & $\begin{array}{c}\text { Uninfected } \\
\text { Mean }( \pm \text { SE) }\end{array}$ & $\begin{array}{c}\text { Infected } \\
\text { Mean }( \pm \text { SE })\end{array}$ & Effect (p) & Percent change from uninfected trees \\
\hline Needle length & $\mathrm{cm}$ & $4.58(0.26)$ & $3.22(0.13)$ & * & -29.7 \\
\hline Needle width & $\mathrm{cm}$ & $0.39(0.02)$ & $0.31(0.01)$ & * & -22.0 \\
\hline Needle area ${ }^{4}$ & $\mathrm{~cm}^{2}$ & $22.08(1.61)$ & $12.94(0.51)$ & * & -41.4 \\
\hline Needle weight ${ }^{4}$ & g & $0.49(0.05)$ & $0.24(0.01)$ & * & -50.3 \\
\hline Specific leaf area ${ }^{4}$ & $\mathrm{~cm}^{2} \mathrm{~g}^{-1}$ & $47.08(1.72)$ & $54.89(1.62)$ & $*$ & 16.6 \\
\hline
\end{tabular}

${ }^{1}$ Scots pine needles, ${ }^{2}$ Scots pine needles plus mistletoe leaves, ${ }^{3}$ Scots pine needles plus mistletoe leaves and branches, ${ }^{4}$ The values belong to 30 sampled needles. 


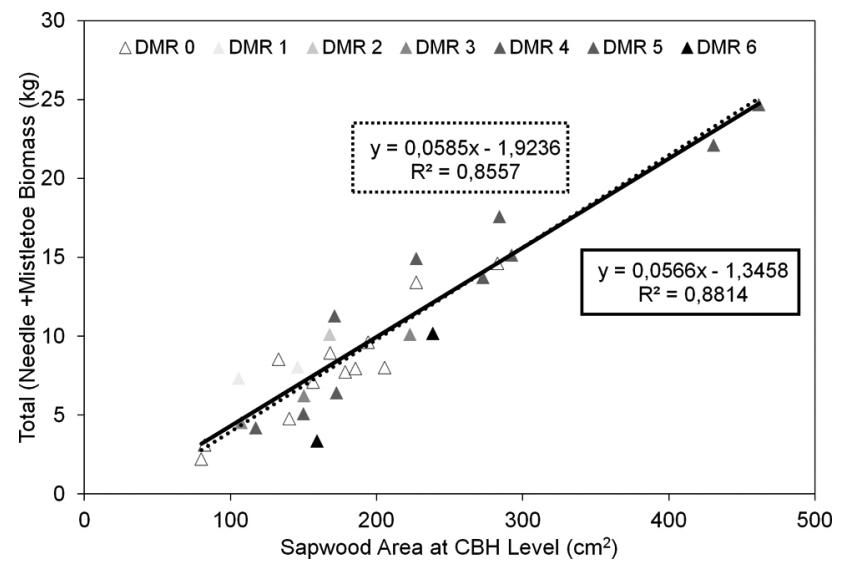

Fig. 3. The relationship between sapwood area at $\mathrm{CB}$ and total green (mistletoe plus needle) biomass. Dashed line represent the relationship for uninfected trees. Solid line represent the relationship for pine mistletoe infected trees

with projected needle area $(\mathrm{r}=0.666, \mathrm{p}<0.01)$ and total leaf area (needle and mistletoe leaf) $(r=0.790$, $\mathrm{p}<0.01)$ in mistletoe infected trees. The relationship between sapwood area at $\mathrm{CBH}$ and total leaf area (needle and mistletoe leaf) was linear for uninfected trees (dashed line), and infected trees (solid line) (Fig 2). No correlation was observed between sapwood area and total leaf area calculated using one-sided mistletoe leaf area plus needle area.

The results of regression analysis indicated that sapwood area at $\mathrm{CBH}$ alone explained $90 \%$ of the variability in total leaf area in uninfected and \%62 of the variability in infected trees (Fig 2).

The results of the Pearson correlation analysis indicated a positive, linear correlations between sapwood area at $\mathrm{CBH}$ and needles in uninfected $(\mathrm{r}=$ $0.925, \mathrm{p}<0.01$ ), and total green biomass (total mistletoe and tree needles) in infected trees ( $r=0.939$, $\mathrm{p}<0.01)$. The results of regression analysis indicated that sapwood area at $\mathrm{CBH}$ alone explained $86 \%$ of the variability in total leaf biomass in uninfected, and, $88 \%$ in infected trees (Fig 3 ). There was no significant difference in total green biomass between infected and uninfected trees (Table 2).

\section{The relationship between sapwood area at crown base and breast height}

Mean sapwood area was lower at crown base height than that at breast height. The difference between sapwood areas at $\mathrm{CBH}$ and $\mathrm{BH}$ increased as the distance between $\mathrm{CBH}$ and $\mathrm{BH}$ increased for infected and uninfected trees. The mean sapwood area was $169.5 \mathrm{~cm}^{2}$ at $\mathrm{CBH}$ and $217.5 \mathrm{~cm}^{2}$ at $\mathrm{BH}$ in uninfected, and $215.4 \mathrm{~cm}^{2}$ at $\mathrm{CBH}$, and $217.6 \mathrm{~cm}^{2}$ at $\mathrm{BH}$ in infected trees. The percent changes in sapwood area from $\mathrm{BH}$ to $\mathrm{CBH}$ were $1.0 \%$ in infected and $22.1 \%$ in uninfected trees. The mean distance from $\mathrm{BH}$ to $\mathrm{CBH}$ was 0.5 and $4.2 \mathrm{~m}$ in infected and uninfected trees, respectively. The t-test results showed that there was no significant differences in sapwood areas at $\mathrm{CBH}$ and $\mathrm{BH}$ in uninfected and infected trees (Table 2). However, the correlation analysis indicated that there was a significant positive correlation between sapwood area at $\mathrm{CBH}$ and $\mathrm{BH}$ level $(r=0.673$, $\mathrm{p}<0.01$ ) in uninfected and infected trees. The regression analysis indicated that distance between $\mathrm{BH}$ and $\mathrm{CBH}$ and sapwood area at $\mathrm{BH}$ were the best predictor of sapwood area at $\mathrm{CBH}$, explaining $89 \%$ of the variability in sapwood area at CBH (Table 3).

\section{Mistletoe characteristics and leaf / branch biomass relationship}

Mistletoe leaf biomass varied from 0.09 to 162.71 $\mathrm{g}$, branch biomass from 0.06 to $336.93 \mathrm{~g}$ and mistletoe age from 2 to 14 in the sampled mistletoes $(n=90)$. Mistletoe sampling results showed that mistletoe leaf/branch biomass ratio decreased exponentially as the mistletoe age increased (Fig 4). The relationship was not linear. A nonlinear relationship indicated that mistletoe age explained $61 \%$ of the variability in mistletoe leaf/branch biomass ratio in sampled mistletoes. (Fig 4).

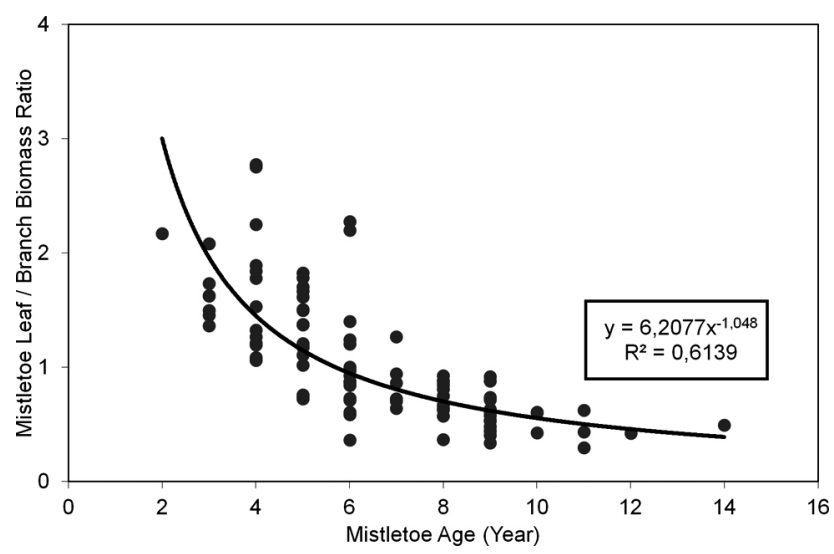

Fig. 4. The relationships between mistletoe leaf/branch biomass ratio and mistletoe age

Table 3. Regression equation and coefficients $(a, b, c)$ for model to predict sapwood area at $\mathrm{CBH}$ in all trees

\begin{tabular}{ccccccr}
\hline Variable $(\mathrm{Y})$ & \multirow{2}{*}{ Unit } & \multirow{2}{*}{ Model form* } & \multicolumn{3}{c}{ Coefficients } & \multicolumn{2}{c}{$\mathrm{R}^{2}$} \\
\hline Sapwood Area at $\mathrm{CBH}$ & $\mathrm{cm}^{2}$ & $Y=a+b\left(\mathrm{AS}_{\mathrm{BH}}\right)+c\left(\right.$ Dist $\left._{(\mathrm{CBH}-\mathrm{BH})}\right)$ & 60.367 & 0.699 & -11.157 & 0.89 \\
\hline
\end{tabular}

${ }^{*} \mathrm{AS}_{\mathrm{BH}}=$ Sapwood area at breast height $\left(\mathrm{cm}^{2}\right)$, Dist ${ }_{(\mathrm{CB}-\mathrm{BH})}=$ Distance between crown base and breast height $(\mathrm{m})$. 


\section{Effects of mistletoe on needle characteristics}

Results show that mistletoe infection causes substantial decrease in needle characteristics. The mean needle length was 4.58 and $3.22 \mathrm{~cm}$, and needle width was 0.39 and $0.31 \mathrm{~cm}$ in uninfected and infected trees, respectively indicating that the mean needle length and width in mistletoe infected trees were 29.7 and $22.0 \%$ lower than those in uninfected trees (Table 2). Needle area was 22.08 and $12.94 \mathrm{~cm}^{2}$, needle weight was 0.49 and $0.24 \mathrm{~g}$, and specific leaf area was 47.08
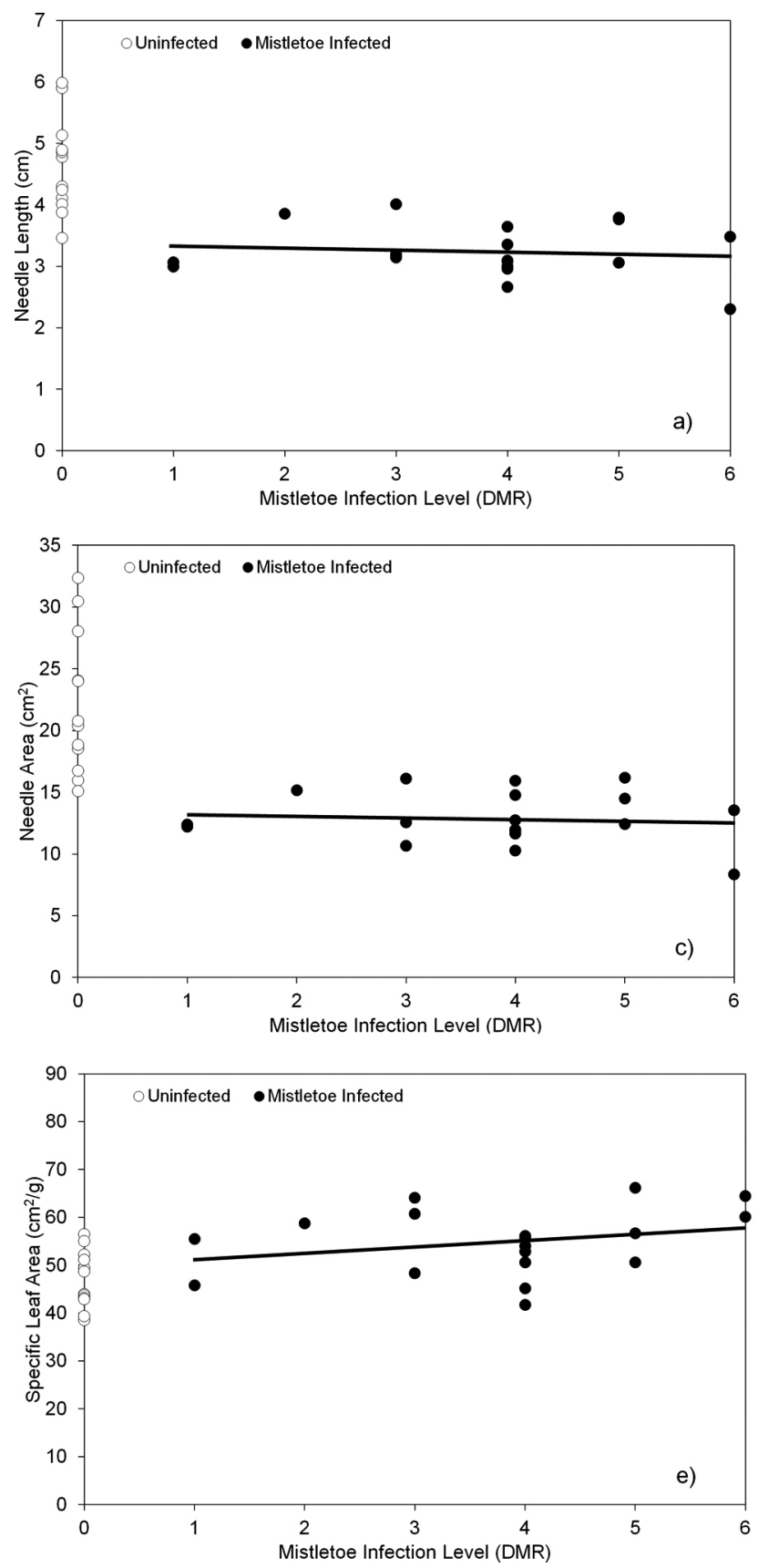

and $54.89 \mathrm{~cm}^{2} \mathrm{~g}^{-1}$ in uninfected and infected trees, respectively (Table 2), showing that mean needle area and needle weight were 41.4 and $50.3 \%$ lower, mean specific leaf area were \%16.6 higher in infected trees, respectively. The t-test results indicate that needle length, needle width, needle area, needle weight and specific leaf area were significantly different in uninfected and infected trees $(\mathrm{p}<0.05)$ (Table 2).

There was also significant negative correlation between mistletoe infection level (DMR) and needle length $(r=-0.651, p<0.01)$, needle width $(r$ $=-0.579, \mathrm{p}<0.01)$, needle weight $(\mathrm{r}=-0.805$,
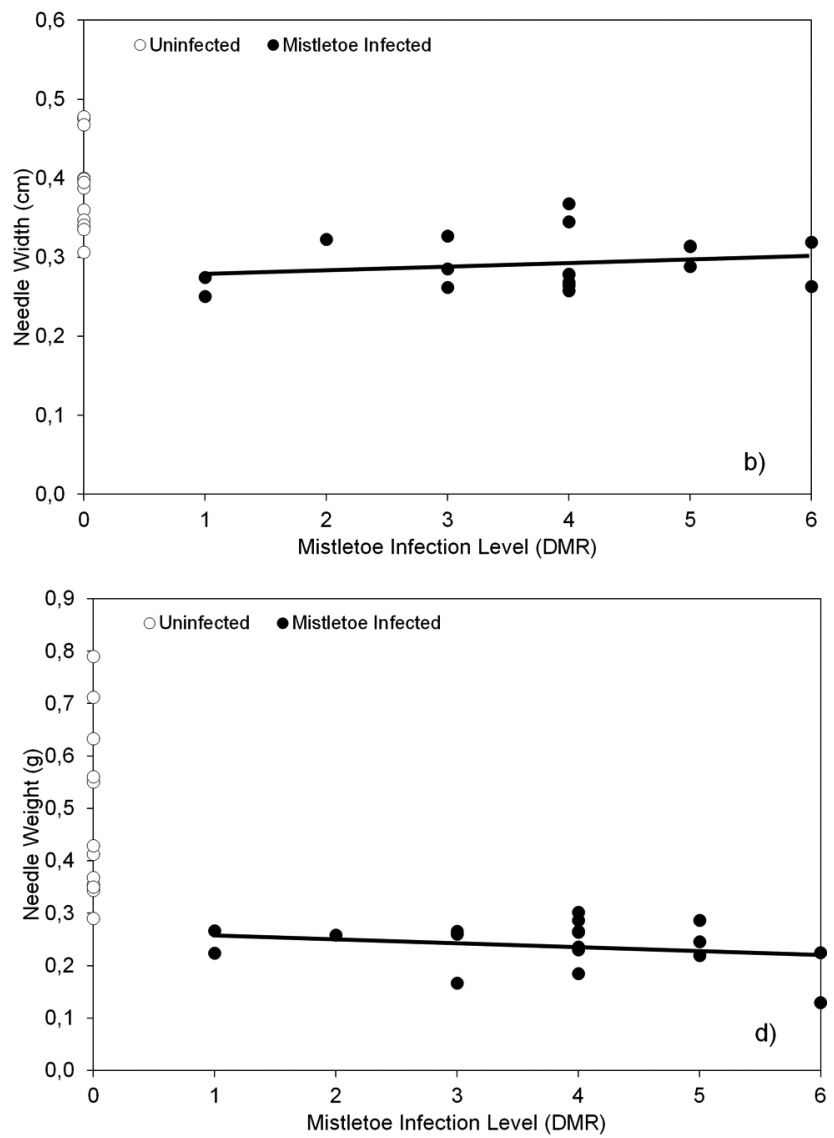

Fig. 5. The relationships between needle length (a), needle width (b), needle area (c) needle weight (d), and specific leaf area (e) and mistletoe infection level (DMR). Solid black lines represent the relationship between mistletoe infected trees, only. Note that needle area (c) and needle weight (d) graphs are based on 30 needle values 
$\mathrm{p}<0.01)$, needle area $(\mathrm{r}=-0.716, \mathrm{p}<0.01)$ and positive correlation between DMR and specific leaf area $(\mathrm{r}=0.533, \mathrm{p}<0.01)$. But, the t-test results (Table 2 ) and the graphical representation of needle length (Fig 5a), needle width (Fig 5b), needle area (Fig 5c), needle weight (Fig 5d) and specific leaf area (Fig 5e) indicated that there were significant differences between uninfected trees and infected trees for all infection classes. There was no significant differences among infection classes (Fig. 5, black solid lines).

\section{Discussion}

\section{Sapwood area - leaf area relationship}

Significant correlation was observed between sapwood area at crown base height and leaf area in uninfected and infected Scots pine trees (Fig. 2). Many researchers have observed and reported a strong correlation between sapwood area at crown base and leaf area (Kaufmann \& Troendle, 1981; Mäkelä et al., 1995; Mencuccini \& Bonosi, 2001; Waring et al., 1982) or leaf biomass (Albrektson, 1984; Berninger \& Nikinmaa, 1994; Eckmullner \& Sterba, 2000; Vanninen et al., 1996) in Scots pine. The high similarity between sapwood area at CBH and needle biomass in uninfected trees, and sapwood area at $\mathrm{CBH}$ and needle biomass plus the mistletoe biomass in mistletoe infected trees indicate that the area of water-conducting xylem (Rigling et al., 2010) is proportional to the total foliage supported as suggested by pipe model theory (Shinozaki et al., 1964).

The relationships between sapwood area at $\mathrm{CBH}$ and leaf area for uninfected and total leaf area (needles plus mistletoe leaves) for infected trees were linear, but with different slopes (Fig. 2). The slope of regression equation for mistletoe infected trees was considerably lower than that of uninfected trees. It should be noted, however, that these relationships are based on needle and mistletoe leaf area, only. Pipe model theory suggests that sapwood area is proportional to the photosynthetic organs (Shinozaki et al., 1964). Therefore, taking only needle and mistletoe leaf area into account may have led to this discrepancy in the slopes (Fig. 2). When total mistletoe biomass (including mistletoe leaves and branches) was included in the analyses, the slopes of regression lines were almost similar. In these relationships, sapwood area at $\mathrm{CBH}$ alone explained $86 \%$ of the variability in total green biomass in uninfected, and $88 \%$ in infected trees (Fig 3). This result clearly indicate that the shedding of mistletoe leaves is compensated for by the branch component of mistletoe. Field observations and the results showed that mistletoe leaf/branch ratio decreased exponentially as the mistletoe age increased (Fig. 4).

\section{The relationship between sapwood area at crown base and breast height}

Although t-test results showed no significant difference, the results of the correlation analysis indicated a significant positive correlation between sapwood area at $\mathrm{CBH}$ and $\mathrm{BH}(\mathrm{r}=0.673, \mathrm{p}<0.01)$ in uninfected and infected trees. These findings are in agreement with the results of a comprehensive study in Scots pine across Europe (Mencuccini \& Bonosi, 2001). They reported that sapwood measurements taken at breast height and at crown base were significantly related $(r=0.80, P<0.05)$ and that significant differences existed in the sapwood areas at the two levels.

As for the changes in sapwood areas along the bole between $\mathrm{BH}$ and $\mathrm{CBH}$, there was a gradual decrease in sapwood areas from $\mathrm{BH}$ to $\mathrm{CBH}$ in both infected and uninfected trees (Table 2). The magnitude of the difference in sapwood areas was related to the distance between $\mathrm{BH}$ and $\mathrm{CBH}$. The average distance and the associated decrease in sapwood area between $\mathrm{BH}$ and $\mathrm{CBH}$ for the infected trees was only $0.5 \mathrm{~m}$ and $2.2 \mathrm{~cm}^{2}$. But, the difference in sapwood areas was more pronounced in the uninfected trees for which the average distance and the associated decrease in sapwood area between $\mathrm{BH}$ and $\mathrm{CBH}$ were $4.2 \mathrm{~m}$ and $48 \mathrm{~cm}^{2}$, respectively (Table 2). These results concur well with some studies indicating a taper (Waring et al., 1982) and a variation in sapwood areas at a measuring point down from the crown base (Albrektson, 1984; Bancalari et al., 1987; Keane \& Weetman, 1987; Mencuccini \& Grace, 1995). Some other studies involving fairly small trees with live crowns down to near breast height reported no differences in the sapwood areas at BH and CBH levels (Kaufmann \& Troendle, 1981). This may explain the lack of difference in sapwood areas in the current study as the infected trees have low crown bases and are usually found in open stands with low crown closure (Bilgili et al., 2020). Therefore, it may be concluded that the results of the study do not provide a conclusive evidence to accept the hypothesis that sapwood areas differ along the stem below crown base in the mistletoe infected Scots pine trees. The dataset provided herewith is limited, and further studies are required to justify the effects of mistletoe infection, if any, on the variation of sapwood along the bole below crown base.

The regression analysis indicated that distance between $\mathrm{BH}$ and $\mathrm{CBH}$, and sapwood area at $\mathrm{BH}$ were the best predictors of sapwood area at $\mathrm{CBH}$, explaining $89 \%$ of the variability in sapwood area at $\mathrm{CBH}$ (Table 3). The results indicated that sapwood area at $\mathrm{CBH}$ is more useful for explaining foliage area/ biomass than that at $\mathrm{BH}$. This result is in an agreement with the findings of Makela et al. (1995) whose 
findings indicated that sapwood area at crown base was a better predictor of foliage biomass and area than that measured at any point below the live crown base in Scots pine.

\section{Effects of mistletoe on needle characteristics}

Pine mistletoe infection influences the anatomical (Ozturk et al., 2019) and morphological (Barbu, 2012; Rigling et al., 2010) characteristics of needles. The results indicated that mean needle length, width and needle area decreased significantly $(\mathrm{p}<0.05)$ as a result of mistletoe infection (Table 2). However, the mean specific leaf area was significantly $(\mathrm{p}<0.05)$ higher in infected trees, and the difference was up to $16.6 \%$ (Table 2). The increase was mainly caused by the substantial decrease in needle weight in infected trees, and similar results were reported in a study on dwarf mistletoe infected spruce trees (Xia et al., 2012).

The changes in average needle characteristics for the whole tree were $29.7 \%$ in needle length, $22.0 \%$ in needle width, $41.4 \%$ in needle area and $50.3 \%$ in needle weight (Table 2). The percent change was greater when needles on branches distal to the mistletoe were considered. These results are in accordance with other similar studies (e.g.,(Barbu, 2012; Rigling et al., 2010).

It is known that needle length is related to water availability (Rigling et al., 2010). The effect of drought on needle size has been documented in many studies in pine species (Dobbertin et al., 2010; Grill et al., 2004; Irvine et al., 1998). The reduction in needle length observed in this study may therefore be ascribed to water stress on trees due to mistletoe infection. Because, it is known that mistletoe exacerbates drought stress (Glatzel \& Geils, 2009; Sanguesa-Barreda et al., 2012) which hinders water availability, and the photosynthetic rate in host leaves is reduced due to mistletoe induced stomatal regulation (Meinzer et al., 2004). Meinzer et al. (2004) found that photosynthetic rate reduction due to mistletoe infection were up to $50 \%$, and correspondingly leaf nitrogen content was $35 \%$ lower in infected trees, and infected branches had only half as much leaf area as did uninfected branches. Similar findings were obtained in the present study. Leaf area reduction in the infected trees was up to $43.4 \%$ in relation to the degree of infection, suggesting that mistletoe related drought stress (Rigling et al., 2010) and altered leaf nitrogen content (Reblin et al., 2006) might be responsible for the reduction in the size of needles. However, the change in the needle length (Fig. 5a), width (Fig. 5b), area (Fig. 5c) and weight (Fig. 5d) reduction with respect to the degree of infection was rather sudden and constant, indicating almost no change throughout the infection levels (DMR). It may thus be suggested that the response of the Scots pine trees is the same irrespective of the mistletoe infection level.

\section{Acknowledgements}

We would like to extend our appreciation and thanks to Torul State Forest Enterprise and its staff. This study was supported by The Scientific and Technological Research Council (TUBITAK) of Turkey. Project No: TOVAG-112O258. We are grateful to anonymous reviewers for their useful suggestions and comments that greatly improved the manuscript.

\section{References}

Albrektson A (1984) Sapwood basal area and needle mass of Scots pine (Pinus sylvestris L) Trees in Central Sweden. Forestry 57: 35-43. doi:10.1093/ forestry/57.1.35.

Bancalari MAE, Perry DA \& Marshall JD (1987) Leaf area - sapwood area relationships in adjacent young Douglas fir stands with different early growth rates. Canadian Journal of Forest Research-Revue Canadienne De Recherche Forestiere 17: 174-180. doi:10.1139/x87-030.

Barbu CO (2012) Impact of White mistletoe (Viscum album ssp abietis) infection on needles and crown morphology of Silver Fir (Abies alba Mill.). Notulae Botanicae Horti Agrobotanici Cluj-Napoca 40: 152-158. doi:10.15835/nbha4027906.

Bartelink HH (1997) Allometric relationships for biomass and leaf area of beech (Fagus sylvatica L). Annales Des Sciences Forestieres 54: 39-50. doi:10.1051/forest:19970104.

Berninger F \& Nikinmaa E (1994) Foliage area - sapwood area relationships of Scots pine (Pinus sylvestris) trees in different climates. Canadian Journal of Forest Research 24: 2263-2268. doi:10.1139/ x94-290.

Bilgili E, Coskuner KA, Baysal I, Ozturk M, Usta Y, Eroglu M \& Norton D (2020) The distribution of pine mistletoe (Viscum album ssp. austriacum) in Scots pine (Pinus sylvestris) forests: from stand to tree level. Scandinavian Journal of Forest Research 35: 20-28. doi:10.1080/02827581.2020.1 729402.

Bilgili E, Ozturk M, Coskuner KA, Baysal I, Serdar B, Yavuz H, Eroglu M \& Usta Y (2018) Quantifying the effect of pine mistletoe on the growth of Scots pine. Forest Pathology 48: 1-9. doi:10.1111/ efp.12435.

Brix H \& Mitchell AK (1983) Thinning and nitrogen fertilization effects on sapwood development and 
relationships of foliage quantity to sapwood area and basal area in Douglas fir. Canadian Journal of Forest Research 13: 384-389. doi:10.1139/x83057.

Dawson TE, King EJ \& Ehleringer JR (1990) Age structure of Phoradendron juniperinum (Viscaceae), a xylem-tapping mistletoe - Inferences from a nondestructive morphological index of age. American Journal of Botany 77: 573-583. doi:10.2307/2444805.

Dobbertin M, Eilmann B, Bleuler P, Giuggiola A, Pannatier EG, Landolt W, Schleppi P \& Rigling A (2010) Effect of irrigation on needle morphology, shoot and stem growth in a drought-exposed $\mathrm{Pi}$ nus sylvestris forest. Tree Physiology 30: 346-360. doi:10.1093/treephys/tpp123.

Eckmullner O \& Sterba H (2000) Crown condition, needle mass, and sapwood area relationships of Norway spruce (Picea abies). Canadian Journal of Forest Research 30: 1646-1654. doi:10.1139/ x00-094.

Ehleringer JR, Cook CS \& Tieszen LL (1986) Comparative water-use and nitrogen relationships in a mistletoe and its host. Oecologia 68: 279-284. doi:10.1007/BF00384800.

Glatzel G \& Geils BW (2009) Mistletoe ecophysiology: host-parasite interactions. Botany 87: 10-15. doi:10.1139/B08-096.

Gol C, Serdar B, Ozturk M, Coskuner KA \& Bilgili E (2018) The effect of Pine mistletoe (Viscum album L. subsp. austriacum (Wiesb.) Vollman) on wood anatomy of Scots pine (Pinus sylvestris L.). Düzce Üniversitesi Bilim ve Teknoloji Dergisi 6: 1354 1363. doi:10.29130/dubited.438455.

Grier CC \& Waring RH (1974) Conifer foliage mass related to sapwood area. Forest Science 20: 205206. doi:10.1093/forestscience/20.3.205.

Grill D, Tausz M, Pollinger U, Jimenez MS \& Morales D (2004) Effects of drought on needle anatomy of Pinus canariensis. Flora 199: 85-89. doi:10.1078/0367-2530-00137.

Hawksworth FG (1977) The 6-class dwarf mistletoe rating system. Rocky Mountain Forest and Range Experiment Station. General Technical Report RM-48.

Holz D (1959) Über das "Anfarben" der Jahrringe an Stammscheiben und Bohrspanen. Archiv für Forstwesen 8: 743-749.

Irvine J, Perks MP, Magnani F \& Grace J (1998) The response of Pinus sylvestris to drought: stomatal control of transpiration and hydraulic conductance. Tree Physiology 18: 393-402. doi:10.1093/ treephys/18.6.393.

Jørgensen HH (2008) Parasitic flowering plants. Brill - Illustrated Edition. Leiden, Netherlands. doi:10.1163/ej.9789004167506.i-438.
Kanat M, Alma MH \& Sivrikaya F (2010) The effect of Viscum album L. on annual diameter increment of Pinus nigra Arn. African Journal of Agricultural Research 5: 166-171. doi:10.5897/AJAR09.482.

Kaufmann MR \& Troendle CA (1981) The relationship of leaf area and foliage biomass to sapwood conducting area in four subalpine forest tree species. Forest Science 27: 477-482. doi:10.1093/ forestscience/27.3.477.

Keane MG \& Weetman GF (1987) Leaf area - sapwood cross-sectional area relationships in repressed stands of Lodgepole Pine. Canadian Journal of Forest Research 17: 205-209. doi:10.1139/ x87-036.

Kendall SJA \& Brown JK (1978) Comparison of tree biomass estimators - DBH and Sapwood area. Forest Science 24: 455-457. doi:10.1093/forestscience/24.4.455.

Kraft G (1884) Beitrage zur lehre von den Durchforstungen, Schlagstellungen und Lichtungshieben, Hannover, Germany, Klindworth's.

Lambers H, Chapin FS \& Pons TL (1998) Plant physiological ecology. Springer-Verlag New York Inc.

Long JN \& Smith FW (1988) Leaf area - sapwood area relations of Lodgepole Pine as influenced by stand density and site index. Canadian Journal of Forest Research 18: 247-250.

Mäkelä A, Virtanen K \& Nikinmaa E (1995) The effects of ring width, stem position, and stand density on the relationship between foliage biomass and sapwood area in Scots pine (Pinus sylvestris). Canadian Journal of Forest Research 25: 970-977. doi:10.1139/x95-105.

Mathiasen RL, Nickrent DL, Shaw DC \& Watson DM (2008) Mistletoes: Pathology, systematics, ecology, and management. Plant Disease 92: 988-1006. doi:10.1094/PDIS-92-7-0988.

Meadows JS \& Hodges JD (2002) Sapwood area as an estimator of leaf area and foliar weight in Cherrybark oak and Green ash. Forest Science 48: 69-76. doi:10.1093/forestscience/48.1.69.

Meinzer FC, Woodruff DR \& Shaw DC (2004) Integrated responses of hydraulic architecture, water and carbon relations of western hemlock to dwarf mistletoe infection. Plant Cell and Environment 27: 937-946. doi:10.1111/j.13653040.2004.01199.x.

Mencuccini M \& Bonosi L (2001) Leaf/sapwood area ratios in Scots pine show acclimation across Europe. Canadian Journal of Forest Research 31: 442-456. doi:10.1139/x00-173.

Mencuccini M \& Grace J (1995) Climate influences the leaf area sapwood area ratio in Scots Pine. Tree Physiology 15: 1-10. doi:10.1093/treephys/15.1.1.

Morikawa Y (1974) Sap flow in Chamaecyparis obtu$s a$ in relation to water economy of woody plants. 
Bulletin of the Tokyo University Forest 66: 251297.

Mutlu S, Ilhan V \& Turkoglu HI (2016a) Mistletoe (Viscum album) infestation in the Scots pine stimulates drought-dependent oxidative damage in summer. Tree Physiology 36: 479-489. doi:10.1093/treephys/tpv135.

Mutlu S, Osma E, Ilhan V, Turkoglu HI \& Atici O (2016b) Mistletoe (Viscum album) reduces the growth of the Scots pine by accumulating essential nutrient elements in its structure as a trap. Trees 30: 815-824. doi:10.1007/s00468-0151323-z.

Ozturk M, Coskuner KA, Usta Y, Serdar B \& Bilgili E (2019) The effect of mistletoe (Viscum album) on branch wood and needle anatomy of Scots pine (Pinus sylvestris). IAWA Journal 40: 352-365. doi:10.1163/22941932-40190219.

Pearson JA, Fahey TJ \& Knight DH (1984) Biomass and leaf area in contrasting Lodgepole pine forests. Canadian Journal of Forest Research 14: 259-265. doi:10.1139/x84-050.

Persoh D, Melcher M, Flessa F \& Rambold G (2010) First fungal community analyses of endophytic ascomycetes associated with Viscum album ssp austriacum and its host Pinus sylvestris. Fungal Biology 114: 585-596. doi:10.1016/j.funbio.2010.04.009.

Reblin JS, Logan BA \& Tissue DT (2006) Impact of eastern dwarf mistletoe (Arceuthobium pusillum) infection on the needles of red spruce (Picea rubens) and white spruce (Picea glauca): oxygen exchange, morphology and composition. Tree Physiology 26: 1325-1332.

Rigling A, Eilmann B, Koechli R \& Dobbertin M (2010) Mistletoe-induced crown degradation in Scots pine in a xeric environment. Tree Physiology 30: 845-852. doi:10.1093/treephys/tpq038.

Rust S (1999) Comparison of three methods for determining the conductive xylem area of Scots pine (Pinus sylvestris). Forestry 72: 103-108. doi:10.1093/forestry/72.2.103.

Sanguesa-Barreda G, Linares JC \& Camarero JJ (2012) Mistletoe effects on Scots pine decline following drought events: insights from within-tree spatial patterns, growth and carbohydrates. Tree Physiology 32: 585-598. doi:10.1093/treephys/ tps031.

Shinozaki K, Yoda K, Hozumi K \& Kira T (1964) A quantitative analysis of plant form; the pipe model theory, I. Basic analyses Japanese Journal of Ecology 14: 97-105. doi:10.18960/seitai.14.3_97. SPSS IC (2015) IBM SPSS Statistics for Windows, Version 23.0: IBM Corp., Armonk, NY.

Tennakoon KU \& Pate JS (1996) Effects of parasitism by a mistletoe on the structure and functioning of branches of its host. Plant Cell and Environment 19: 517-528. doi:10.1111/j.1365-3040.1996. tb00385.x.

Tinnin RO \& Knutson DM (1980) Growth characteristics of the brooms on Douglas-fir caused by $A r$ ceuthobium douglasii. Forest Science 26: 149-158. doi:10.1093/forestscience/26.1.149.

TSMS (2020) Gumushane meteorological station, 1961-2018 meteorological values. Turkish State Meteorological Service.

Ullmann I, Lange OL, Ziegler H, Ehleringer J, Schulze ED \& Cowan IR (1985) Diurnal courses of leaf conductance and transpiration of mistletoes and their hosts in central Australia. Oecologia 67: 577-587. doi:10.1007/BF00790030.

Vanninen P, Ylitalo H, Sievänen R \& Mäkelä A (1996) Effects of age and site quality on the distribution of biomass in Scots pine (Pinus sylvestris L.). Trees 10: 231-238. doi:10.1007/BF02185674.

Waring RH, Schroeder PE \& Oren R (1982) Application of the Pipe Model-Theory to predict canopy leaf area. Canadian Journal of Forest Research 12: 556-560. doi:10.1139/x82-086.

Whitehead D (1978) The estimation of foliage area from sapwood basal area in Scots pine. Forestry 51: 137-149. doi:10.1093/forestry/51.2.137.

Xia B, Tian CM, Luo YQ, Liu LY, Cairang DZ, Ma JH \& Han FZ (2012) The effects of Arceuthobium sichuanense infection on needles and current-year shoots of mature and young Qinghai spruce (Picea crassifolia) trees. 42: 330-337. doi:10.1111/ j.1439-0329.2011.00760.x. 